\title{
IMPLEMENTASI SISTEM MANAJEMEN MUTU ISO 9001:2008 DI BADAN AMIL ZAKAT NASIONAL
}

\section{IMPLEMENTATION OF QUALITY MANAGEMENT SYSTEM ISO 9001:2008 IN BADAN AMIL ZAKAT NASIONAL}

\author{
W. Munawar ${ }^{1}$ dan Qomaruddin ${ }^{2}$ \\ 1Program StudiEkonomi Islam Fakultas Ekonomi Islam Universitas Djuanda, Jl. Tol Ciawi No. 1, \\ Kotak Pos 35 Bogor 16720. \\ 2Program Studi Ekonomi Islam Fakultas Ekonomi Islam Universitas Djuanda, Jl. Tol Ciawi No. 1, \\ Kotak Pos 35 Bogor 16720.
}

\begin{abstract}
This study aims to find out the quality management system and its implementation based on the quality management system ISO 9001: 2008 in BAZNAS. The method used is descriptive method with quantitative approach. Analysis technique used is the analysis of factors and Importance Performance Analysis (IPA). The results showed that the quality management system consists of five structures BAZNAS documentation, that the quality policy, quality manual, quality procedures, work instructions, and document records. The results of factor analysis showed that the main factor in the implementation of QMS ISO 9001: 2008 still is considered a contributing factor, and there is also a supporting factor that is considered a major factor. While the implementation of QMS ISO 9001: 2008 in BAZNAS through analysis Importance Performance Analysis (IPA) is expressed in accordance with ISO 9001: 2008, but there are variables that implementation is low, namely planning (5) and infrastructure (9), so that the variables need to be increased.
\end{abstract}

Keywords: Implementation of Quality Management System, ISO

\begin{abstract}
ABSTRAK
Penelitian ini bertujuan untuk mengetahui sistem manajemen mutu dan implementasinya berdasarkan sistem manajemen mutu ISO 9001: 2008 di BAZNAS. Metode penelitian yang digunakan adalah metode deskriptif pendekatan kuantitatif dengan teknik analisis data yang digunakan adalah analisis faktor dan Importance Performance Analysis (IPA). Hasil penelitian menunjukkan bahwa sistem manajemen mutu BAZNAS terdiri dari lima struktur dokumentasi yaitu kebijakan mutu, pedoman mutu, prosedur mutu, instruksi kerja, dan dokumen rekaman. Hasil analisis faktor menunjukkan bahwa faktor utama dalam implementasi SMM ISO 9001: 2008 masih ada yang dianggap menjadi faktor pendukung dan ada juga faktor pendukung yang dianggap menjadi faktor utama. Sedangkan implementasi SMM ISO 9001: 2008 di BAZNAS melalui analisis Importance Performance Analysis (IPA) dinyatakan telah sesuai dengan ISO 9001: 2008, akan tetapi masih terdapat variabel-variabel yang implementasinya rendah yaitu perencanaan dan sarana dan prasarana, sehingga variabel tersebut perlu ditingkatkan.

Kata kunci: Implementasi Sistem Manajemen Mutu, ISO
\end{abstract}

Munawar, Wildan. 2016. Implementasi sistem manajemen mutu ISO 9001:2008 Di Badan Amil Zakat Nasional. Jurnal Syarikah 2 (1). Hal 149-167. 


\section{PENDAHULUAN}

Zakat merupakan ibadah kepada Allah SWT yang memiliki tujuan untuk mendekatkan diri kepadaNya dan menolong manusia dari kemiskinan dan kesengsaraan. Zakat pula bertujuan untuk mensucikan harta seseorang, mengikis manusia dari sifat keserakahan, dan mencegah penumpukan harta kekayaan pada sebagian orang, sebagaimana telah dipaparkan dalam Al-Qur'an Surat attaubah: 103.

Zakat yang ditunaikan oleh setiap orang harus diatur dan dikelola secara melembaga agar sesuai dengan ketentuan syariat Islam dan aturan negara. Maka dari itu, negara berinisiasi untuk membentuk lembaga zakat tersendiri dibawah koordinasi departemen agama dengan nama Badan Amil Zakat Nasional (BAZNAS). BAZNAS sebagai lembaga amanah yang mengelola zakat dituntut untuk memberikan pelayanan yang terbaik kepada muzaki dan memberikan program yang dapat meningkatkan kesejahteraan para mustahiknya. Dengan keberhasilan pelayanan dan program yang dikeluarkan BAZNAS, menjadi bukti konkret dalam menjaga kepercayaan masyarakat. Oleh karena itu, untuk menjaga kepercayaan tersebut, BAZNAS perlu meningkatkan kualitas dengan adanya penjaminan mutu. Adanya penjaminan mutu ini diharapkan setiap aktivitas dan proses pengelolaan zakat dapat berjalan dengan baik.

Untuk mengatur penjaminan mutu, maka diperlukan sistem yang dapat dijadikan sebagai standar dalam mengembangkan kinerja dan proses kelembagaan secara konsisten. Sistem yang biasa digunakan dalam penjaminan mutu adalah ISO 9001:2008 yang berorientasi kepada kepuasan pelanggan dengan diterapkannya sistem manajemen mutu.

Dalam ISO 9001:2008 terdapat aturanaturan yang harus diikuti oleh lembaga atau organisasi jika ingin meningkatkan kepuasan pelanggannya. Dengan sistem ini, lembaga atau organisasi diarahkan untuk selalu mengendalikan mutunya, baik dalam kebijakan, tujuan, maupun programnya.

BAZNAS sebagai lembaga zakat yang telah mengimplementasikan sistem manajemen mutu sejak tahun 2009, telah mendapatkan sertifikasi ISO 9001:2008 yang pertama kalinya untuk kategori seluruh unit kerja. Sertifikasi tersebut telah diperoleh sampai dengan saat ini. Oleh karena itu, dengan perolehan sertikasi ISO 9001:2008 tersebut, BAZNAS dituntut untuk selalu meningkatkan kualitas kinerja dan pelayanan kepada para muzaki dan mustahiknya. Maka dari itu, sistem manajemen mutu ISO 9001:2008 ini menjadi penting bagi BAZNAS untuk diimplementasikan pada setiap unit kerjanya.

\section{MATERI DAN METODE}

Banyak pendapat dari para ahli yang menjabarkan tentang definisi manajemen, seperti John D. Millet, James A.F. Stoner, Charles Wankel, Paul Hersey, dan Kenneth H. Dari pendapat tersebut menyimpulkan bahwa manajemen adalah salah satu ilmu dalam melakukan perencanaan, pengorganisasian, pengarahan, pemotivasian, dan pengendalian terhadap orang-orang dan mekanisme kinerja untuk mencapai tujuan tertentu (Siswanto, 2005: 2). Sedangkan dalam mendefinisikan mutu terdapat pula para pakar yang telah menjelaskannya, diantaranya Juran, Crosby, Deming, Feigenbaum, dan Garvin. Dari penjelasan definisi tersebut terlihat adanya 
kesamaan, sehingga mutu dapat didefinisikan sebagai usaha yang mencakup pemenuhan harapan pelanggan, baik produk atau jasa, proses dan keadaan yang selalu berubah (Nasution, 2001: 16). Adapun definisi dari manajemen mutu adalah suatu kegiatan yang terkoordinasi untuk mengarahkan dan mengendalikan lembaga atau organisasi dalam hal mutu (SNI ISO 9001:2008, 2016). Dalam manajemen mutu dikenal istilah manajemen mutu terpadu (Total Quality Mangement). Manajemen mutu terpadu merupakan sistem manajemen mutu yang menjadikan kualitas sebagai fokus utama dan strategi dalam memberikan kepuasan kepada pelanggan dengan melibatkan seluruh anggota organisasi (Nasution, 2001:28).

Manajemen mutu terpadu tidak terlepas dari tuntunan syariat Islam yang mengatur di dalamnya. Dalam Islam, setiap manajemen yang berjalan selalu dilandasi dengan asas dan nilai-nilai ketauhidan, sehingga pelakunya diharapkan akan terkendali dan terhindar dari perilaku yang tercela, seperti Korupsi, Kolusi dan Nepotisme (Hafidhuddin dkk, 2003: 5). Berkenaan dengan manajemen mutu dalam syariat Islam yang menitikberatkan pada kepuasan pelanggan, maka Allah SWT telah menegaskan dalam Al-Qur'an surat AsySyu'ara: 183.
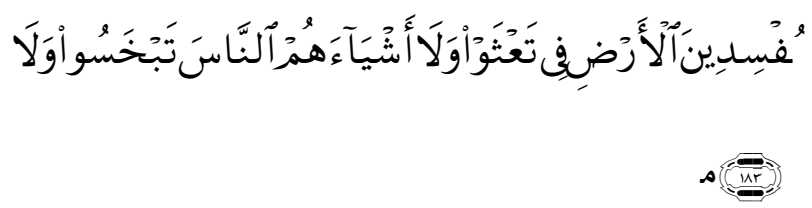

"Dan janganlah kamu merugikan manusia pada hak-haknya dan janganlah kamu merajalela di muka bumi dengan membuat kerusakan." (QS. AsySyu'ara:183)
Berdasarkan ayat di atas menjelaskan bahwa kita dilarang merugikan manusia atas hak-haknya dan berbuat kerusakan atasnya. Hal ini berarti bahwa pelanggan akan puas jika perusahaan tidak melakukan kerugian dengan cara meningkatkan pelayanan atau membuat produk yang melebihi kebutuhan dan harapan pelanggannya.

Manajemen mutu akan terwujud dengan adanya sebuah sistem yang mengaturnya bernama sistem manajemen mutu. Sistem manajemen mutu awal kali dikenalkan pada tahun 1987 melalui International Organization for Standardization (ISO) yang kemudian dinamai ISO 9000:1987. Seiring dengan perkembangan zaman dan kemudian mengalami revisi dari ISO 9000:1987 menjadi ISO 9000:1994, ISO 9001:2000, ISO 9001:2008 dan yang terbaru ISO 9001:2015. Dari standar tersebut, saat ini ISO 9001:2008 yang paling banyak digunakan. Dalam ISO 9001:2008 telah menentukan persyaratan-persyaratan dan rekomendasi untuk perbaikan yang berkelanjutan dari sistem manajemen mutu. Adapun persyaratan-persyaratan yang terdapat dalam sistem manajemen mutu ISO 9001:2008 terdiri dari klausulklausul berikut ini:

Klausul 1. Lingkup; menentukan persyaratan sistem manajemen mutu yang dapat diimplemetasikan oleh setiap organisasi, baik besar maupun kecil, termasuk jenis, ukuran, dan produk yang dihasilkan.

Klausul 2. Acuan normatif; SNI ISO 9000:2005 tentang sistem manajemen mutu: dasar-dasar dan kosakata.

Klausul 3. Istilah dan definisi; serupa dengan istilah dan definisi yang ada dalam ISO 9000. Namun, dalam standar ini 
apabila ditemukan istilah produk dapat juga berarti jasa.

Klausul 4. Sistem manajemen mutu; terdapat syarat yang harus diperhatikan, yaitu persyaratan secara umum dan persyaratan dokumentasi yang mencakup kebijakan mutu, sasaran mutu, pedoman mutu, prosedur dan rekaman yang terdokumentasi.

Klausul 5. Tanggung jawab manajemen; terdapat enam syarat yang harus dijalankan oleh manajemen yaitu komitmen manajemen, fokus pada pelanggan, kebijakan mutu yang sesuai dengan sasaran organisasi, perencanaan sasaran, tanggung jawab, wewenang dan komuniasi, serta tinjauan manajemen.

Klausul 6. Pengelolaan sumber daya; memperhatikan syarat-syarat seperti penyediaan sumber daya yang diperlukan, sumber daya manusia yang kompeten, sarana dan prasarana, serta lingkungan kerja.

Klausul 7. Realisasi produk; berkaitan dengan perencanaan realisasi produk yang konsisten dengan persyaratan proses sistem manajemen mutu dan pelanggan.

Klausul 8. Pengukuran, analisis, dan perbaikan; berkaitan dengan pemantauan dan pengukuran melalui persepsi kepuasan pelanggan, audit internal, pemantauan dan pengukuran proses yang sesuai serta perbaikan secara berkesinambungan melalui penggunaan kebijakan mutu, sasaran mutu, hasil audit, analisis data, tindakan korektif, preventif, dan tinjauan manajemen.

Badan Amil Zakat Nasional (BAZNAS) sebagai lembaga zakat yang melakukan perencanaan, pelaksanaan, dan pengoordinasian dalam penghimpunan, pendistribusian, dan pendayagunaan zakat perlu membentuk dewan pengurus yang akan mengelola setiap kegiatannya. Dewan pengurus tersebut terdiri dari ketua atau direktur, bagian penyaluran zakat, bagian keuangan, koordinator program, bagian pembinaan mustahik, dan bagian pengumpulan dana ZIS (Huda, 2010: 308). Dengan adanya dewan pengurus tersebut, kinerja pengelolaan zakat dari mulai perencanaan sampai evaluasi dapat berjalan secara profesional dan sesuai dengan tuntunan syariat Islam serta aturan perundang-undangan yang berlaku.

Penelitian terdahulu yang pernah dilakukan oleh Rusdiana (2010) mengenai analisis penerapan ISO 9001:2000 pada Badan Amil Zakat Nasional, Jakarta dengan menggunakan metode analisis deskriptif kualitatif dan Analisis Hierarki Proses (AHP) memberikan kesimpulan bahwa penerapan ISO pada BAZNAS telah dilakukan sejak tahun 2007, dimana seluruh persyaratan atau klausul dalam ISO 9001:2000 telah dipenuhi dan dilaksanakan dengan baik. Dari penelitian terdahulu ini, maka penulis merangkainya dalam suatu kerangka pemikiran sebagai berikut:

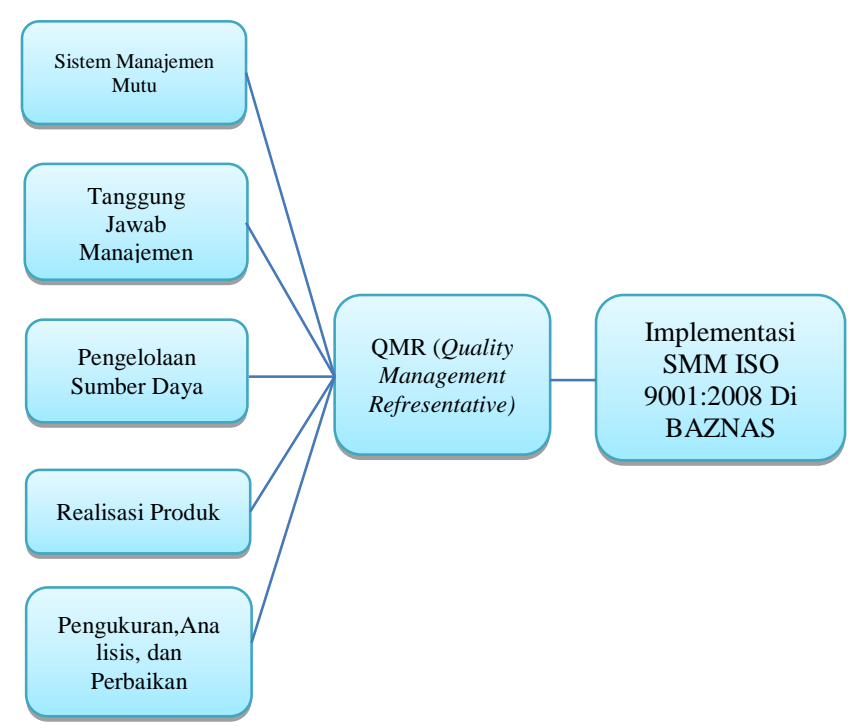

Gambar 1. Kerangka Pemikiran 
ISO 9001:2008 merupakan standar manajemen mutu yang berorientasi dalam meningkatkan kepuasan pelanggan yang dapat digunakan oleh setiap organisasi maupun lembaga, termasuk lembaga zakat seperti BAZNAS. Standar ISO 9001:2008 tersebut memiliki klausul yang menjadi persyaratan dalam implementasi sistem manajemen mutu yaitu sistem manajemen mutu, tanggung jawab manajemen, pengelolaan sumber daya, realisasi produk, dan pengukuran, analisis dan perbaikan. Implementasi setiap klausul-klausul tersebut dilaksanakan dan ditinjau langsung oleh Quality Management Refresentative (QMR) yang ada di BAZNAS, sehingga setiap divisinya bertanggung jawab atas penerapan sistem manajemen mutu tersebut.

Metode penelitian ini menggunakan metode deskriptif yang dianalisa dengan pendekatan kuantitatif. Metode ini digunakan bertujuan untuk memberikan penjelasan secara terperinci tentang pelaksanaan sistem manajemen mutu ISO 9001:2008 di BAZNAS. Populasi dan sampel dalam penelitian ini adalah Badan Amil Zakat Nasional yang meliputi seluruh unit yang ada di Badan Amil Zakat Nasional. Adapun sampel dalam penelitian ini berjumlah 30 orang dengan menggunakan teknik purposive sampling yaitu teknik penentuan sampel berdasarkan pertimbangan tertentu (Sugiyono, 2014: 85).

Jenis dan sumber data dalam penelitian ini berasal dari data primer dan sekunder dengan pengumpulan data melalui wawancara, kuesioner, dan data pendukung lainnya, seperti dokumen internal BAZNAS, buku, dan bahan pustaka lainnya. Sedangkan teknik analisis data yang digunakan adalah uji reliabilitas dan validitas, analisis faktor, dan Importance Performance Analysis (IPA).

Sebelum menyebarkan kuesioner, terlebih dahulu dilakukan pengujian dengan uji validitas dan reliabilitas. Uji validitas dalam penelitian ini menggunakan metode korelasi product moment atau pengujian dengan cara mengkorelasikan skor butir pada kuesioner dengan skor totalnya. Rumus metode korelasi product moment adalah:

$$
\begin{aligned}
& r x y \\
& =\frac{N(\Sigma \mathrm{XY})-(\Sigma \mathrm{X})(\Sigma \mathrm{Y})}{\sqrt{\left[\left\{N\left(\Sigma X^{2}\right)-\left(\Sigma X^{2}\right)\right\}\left\{N\left(\Sigma Y^{2}\right)-(\Sigma \mathrm{Y})^{2}\right\}\right]}}
\end{aligned}
$$

Keterangan

rxy: Nilai korelasi product moment

$\mathrm{N}$ : Jumlah responden

$\Sigma \mathrm{X}$ : Jumlah skor butir pertanyaan

$\Sigma Y$ : Jumlah skor total

$\Sigma \mathrm{X} 2$ :Jumlah skor butir pertanyaan (x)

$\Sigma Y 2$ : Jumlah skor total kuadrat (y)

$\Sigma X Y$ :Jumlah perkalian butir pertanyaan

(x) dan skor total (y)

Setelah uji validitas, dilakukan uji reliabilitas dengan menggunakan rumus Cronbach's Alpha yaitu sebagai berikut:

$$
r i i=\left(\frac{k}{k-1}\right)\left(1-\frac{\Sigma \sigma b^{2}}{\sigma^{2} t}\right)
$$

Keterangan

$$
\begin{array}{ll}
\text { rii } & : \text { Reliabilitas instrumen } \\
\mathrm{k} & : \text { Banyak butir pertanyaan } \\
\sigma \mathrm{t} 2 & : \text { Varian total }
\end{array}
$$

$\Sigma \sigma b 2 \quad$ : Jumlah varian butir

Untuk mengetahui faktor-faktor yang menjadi faktor dominan dan pendukung dalam penerapan sistem manajemen mutu dirumuskan dengan menggunakan analisis faktor. Analisis faktor didefinisikan sebagai salah satu bentuk analisis multivariat yang 
memiliki fungsi untuk menemukan satu atau beberapa variabel. Analisis faktor tersebut diuji terlebih dahulu dengan menggunakan uji kaiser mayer olkin (KMO) sebagai berikut:

$$
\begin{aligned}
& \qquad K M O=\frac{\sum_{i}^{n} \sum_{j \neq i}^{n} r_{i j}^{2}}{\sum_{i}^{n} \sum_{j \neq i}^{n} r_{i j}^{2}+\sum_{i}^{n} \sum_{j \neq i}^{n} a_{i j}^{2}} \\
& \mathrm{i}=1,2,3, \ldots ., \mathrm{p} \text { dan } \mathrm{j}=1,2,3, \ldots ., \mathrm{p} \\
& \text { keterangan: }
\end{aligned}
$$

$\mathrm{rij}^{2}$ adalah koefisien korelasi sederhana dari variabel i dan j.

$\mathrm{a}_{\mathrm{ij}}{ }^{2}$ adalah koefisien korelasi parsial dari variabel i dan j.

Dalam penelitian ini, faktor-faktor yang kemungkinan menjadi indikator dalam implementasi SMM ISO 9001:2008 di BAZNAS meliputi 5 faktor, yaitu sistem manajemen mutu $\left(\mathrm{F}_{1}\right)$, tanggung jawab manajemen $\left(F_{2}\right)$, pengelolaan sumber daya $\left(F_{3}\right)$, realisasi produk $\left(F_{4}\right)$, dan pengukuran, analisis dan perbaikan $\left(\mathrm{F}_{5}\right)$. Dari kelima faktor tersebut, masing-masing memiliki beberapa variabel, yaitu:

a. $F_{1}$ (SMM), memiliki variabel manual mutu $\left(\mathrm{X}_{1}\right)$, pengendalian dokumen $\left(\mathrm{X}_{2}\right)$, dan pengendalian rekaman $\left(\mathrm{X}_{3}\right)$.

b. $F_{2}$ (tanggung jawab manajemen), memiliki variabel komitmen manajemen $\left(\mathrm{X}_{1}\right)$, fokus pada pelanggan $\left(\mathrm{X}_{2}\right)$, kebijakan mutu $\left(\mathrm{X}_{3}\right)$, perencanaan $\left(\mathrm{X}_{4}\right)$, tanggung jawab, wewenang, dan komunikasi $\left(\mathrm{X}_{5}\right)$, dan tinjauan manajemen $\left(\mathrm{X}_{6}\right)$.

c. $\mathrm{F}_{3}$ (pengelolaan sumber daya), memiliki variabel penyediaan sumber daya $\left(\mathrm{X}_{1}\right)$, sumber daya manusia $\left(\mathrm{X}_{2}\right)$, prasarana $\left(\mathrm{X}_{3}\right)$, dan lingkungan kerja $\left(\mathrm{X}_{4}\right)$.

d. $\mathrm{F}_{4}$ (realisasi produk), memiliki variabel perencanaan $\left(\mathrm{X}_{1}\right)$, proses yang berkaitan dengan pelanggan $\left(\mathrm{X}_{2}\right)$, desain dan pengembangan $\left(\mathrm{X}_{3}\right)$, pembelian $\left(\mathrm{X}_{4}\right)$, produksi dan penyediaan jasa $\left(\mathrm{X}_{5}\right)$, dan pengendalian sarana pemantauan dan pengukuran $\left(\mathrm{X}_{6}\right)$.

e. $\mathrm{F}_{5}$ (pengukuran, analisis dan perbaikan), memiliki variabel pemantauan dan pengukuran $\left(\mathrm{X}_{1}\right)$, pengendalian produk yang tidak sesuai $\left(\mathrm{X}_{2}\right)$, analisis data $\left(\mathrm{X}_{3}\right)$, dan perbaikan $\left(\mathrm{X}_{4}\right)$.

Dari kelima faktor tersebut, maka dapat dirumuskan model matematis sebagai berikut:

$$
\begin{aligned}
F_{1}= & a_{11} X_{1}+a_{12} X_{2}+a_{13} X_{3} \\
F_{2}= & a 21 X_{1}+a_{22} X_{2}+a_{23} X_{3}+a_{24} X_{4}+a_{25} X_{5} \\
& +a_{26} X_{6} \\
F_{3}= & a_{31} X_{1}+a_{32} X_{2}+a_{33} X_{3}+a_{34} X_{4} \\
F_{4}= & a_{41} X_{1}+a_{42} X_{2}+a_{43} X_{3}+a_{44} X_{4}+a_{45} X_{5} \\
& +a_{46} X_{6} \\
F_{5}= & a_{51} X_{1}+a_{52} X_{2}+a_{53} X_{3}+a_{54} X_{4}
\end{aligned}
$$

Teknik Importance Performance Analisis (IPA) digunakan bertujuan untuk mengidentifikasi sejauh mana implementasi sistem manajemen mutu yang dilaksanakan oleh BAZNAS berdasarkan ISO 9001:2008 dengan memposisikan tingkat kepentingan atas kinerja dan kenyataan yang terjadi di lapangan dalam matriks IPA. Matriks IPA terdiri dari empat kuadran yang akan menjelaskan kondisi masing-masing faktor yang telah diimplementasikan. Kondisikondisi tersebut yaitu:

Kuadran A. Dalam kuadran ini terdapat faktor-faktor yang dianggap penting oleh amilin. Akan tetapi, dalam implementasinya saat ini masih kurang diperhatikan. Sehingga faktor ini harus ditingkatkan.

Kuadran B. Kuadran ini memuat faktorfaktor yang dianggap penting dan implementasinya sudah sesuai dengan 
harapan. Maka dari itu, faktor ini harus tetap dipertahankan.

Kuadran C. Dalam kuadran ini terdapat faktor-faktor yang dianggap kurang penting dan tingkat implementasinya menjadi berkurang. Maka dari itu, peningkatan faktor ini perlu diperhatikan, meskipun dianggap tidak terlalu penting.

Kuadran D. Kuadran ini memuat faktor-faktor yang dianggap tidak terlalu penting, sedangkan implementasinya dianggap berlebihan sehingga harus melakukan efisiensi terhadap faktor-faktor ini.

Menurut Martinez (2003) terdapat dua macam metode dalam menampilkan data IPA, yaitu: pertama menempatkan garis perpotongan kuadran pada nilai rata-rata pada sumbu tingkat implementasi dan sumbu klausul ISO 9001:2008 dengan tujuan untuk mengetahui secara umum penyebaran data terletak pada kuadran berapa. Metode kedua yaitu dengan menempatkan garis perpotongan kuadran pada nilai rata-rata hasil pengamatan pada sumbu tingkat implementasi dan sumbu klausul ISO 9001:2008 dengan tujuan untuk mengetahui secara spesifik masingmasing faktor terletak pada kuadran berapa. Dalam menggunakan metode IPA, perlu diperhatikan prosedur penggunaannya, yaitu:

a. Penentuan faktor-faktor yang akan dianalisis.

b. Melakukan survei melalui penyebaran kuesioner.

c. Menghitung nilai rata-rata tingkat implementasi dan klausul ISO 9001:2008.

d. Membuat grafik IPA.

e. Melakukan evaluasi terhadap faktor yang sesuai dengan kuadran masingmasing.

\section{HASIL DAN PEMBAHASAN}

Badan Amil Zakat Nasional (BAZNAS) adalah badan amil zakat yang memiliki tugas dan fungsi menghimpun dan menyalurkan zakat, infak, dan shadaqah (ZIS) pada tingkat nasional. BAZNAS sebagai lembaga pengelola zakat perlu menetapkan visi, misi, tugas pokok, struktur organisasi dan program yang berkaitan dengan pendistribusian dan pendayagunaan zakat. Adapun visi, misi, tugas pokok, struktur organisasi, layanan, dan program BAZNAS adalah sebagai berikut:

\section{Visi dan Misi BAZNAS}

a. Visi BAZNAS

"Menjadi Badan Zakat Nasional yang Amanah, Transparan dan Profesional."

b. Misi BAZNAS

Adapun misi BAZNAS adalah sebagai berikut:

1. Meningkatkan kesadaran umat untuk berzakat melalui amil zakat.

2. Meningkatkan penghimpunan dan pendayagunaan zakat nasional sesuai dengan ketentuan syariah dan prinsip manajemen modern.

3. Menumbuh kembangkan pengelola/amil zakat yang amanah, transparan, profesional, dan terintegrasi.

4. Mewujudkan pusat data zakat nasional.

5. Memaksimalkan peran zakat dalam menanggulangi kemiskinan di Indonesia melalui sinergi dan koordinasi dengan lembaga terkait.

\section{Tugas Pokok BAZNAS}

Tugas pokok yang harus dilaksanakan oleh BAZNAS adalah sebagai berikut:

a) Meningkatkan kesadaran umat untuk berzakat. 
b) Mengarahkan masyarakat mencapai kesejahteraan baik fisik maupun nonfisik melalui pendayagunaan zakat.

c) Meningkatkan status mustahik menjadi muzaki melalui pemulihan, peningkatan mutu SDM dan pengembangan ekonomi masyarakat.

d) Mengembangkan budaya "memberi lebih baik dari menerima" di kalangan mustahik.

e) Mengembangkan manajemen yang amanah, profesional dan transparan dalam mengelola zakat.

\section{Struktur Organisasi BAZNAS}

Berdasarkan Keppres RI No. 8 Tahun 2001, kepengurusan BAZNAS terdiri dari badan pelaksana, dewan pertimbangan, dan komisi pengawas. Badan pelaksana akan menunjuk seorang direktur eksekutif sebagai pelaksana harian kegiatan operasional BAZNAS. Direktur eksekutif menunjuk Wakil Manajemen Mutu atau QMR yang bertanggung jawab mengawasi dan mengendalikan BAZNAS agar sesuai dengan implementasi ISO 9001:2008. Selain itu, dalam proses implementasi ISO 9001:2008 BAZNAS memiliki divisi-divisi yang akan membantu direktur eksekutif dalam menjalankan tugasnya. Adapun divisi-divisi BAZNAS yang mendukung dalam implementasi ISO 9001:2008 adalah:

a) Divisi Penghimpunan

b) Divisi Pendistribusian dan Pendayagunaan

c) Divisi Sumber Daya Manusia

d) Divisi Keuangan

e) Divisi Teknologi Informasi dan Umum

f) Divisi Corporate Secretary dan Legal

g) Divisi Koordinator Zakat Nasional

h) Divisi Perencanaan dan Pengembangan

\section{Layanan-Layanan BAZNAS}

Dalam meningkatkan kepuasan dan kemudahan para muzaki dalam membayar zakat, maka BAZNAS membuka layananlayanan yang menunjang terhadap peningkatan penghimpunan dana zakat. Layanan-layanan BAZNAS tersebut adalah zakat via payroll system adalah sebuah bentuk pelayanan dalam membayar zakat dengan cara memotong langsung dari gaji karyawan di sebuah perusahaan. Zakat Via BizZakat merupakan layanan Mobil Zakat Keliling yang secara periodik ditempatkan dibeberapa lokasi strategis guna memudahkan muzaki melakukan pembayaran ZIS nya.

Zakat Via E-Card merupakan layanan fasilitas pembayaran melaui menu pembayaran zakat di ATM. Zakat Via Online Payment adalah layanan pembayaran ZIS dan donasi lain melalui mekanisme online payment atau e-payment yang bekerjasama dengan pihak perbankan syariah dan konvensional. Zakat Via Layanan Perbankan Syariah. Layanan yang memudahkan muzaki untuk membayar zakat disemua bank syariah, karena BAZNAS telah memiliki rekening yang bekerjasama dengan seluruh perbankan syariah.

Zakat Via Kounter merupakan layanan bagi para muzaki agar mendapatkan pelayanan yang lebih dekat dan eksklusif, tidak hanya untuk membayarkan zakat, akan tetapi dapat berkonsultasi seputar ZIS serta informasi lengkap mengenai program BAZNAS. Konsultasi Online merupakan layanan bagi muzaki untuk berkonsultasi secara langsung kepada BAZNAS melalui online. Konfirmasi pembayaran zakat merupakan layanan yang dapat memudahkan muzaki ketika sudah membayar zakat. 
Registrasi Online adalah layanan bagi masyarakat untuk mendaftar sebagai muzaki secara online. Jemput zakat merupakan layanan untuk menjemput dana zakat dari muzaki secara langsung. Muzaki corner merupakan layanan khusus muzaki dalam rangka konfirmasi pembayaran zakat. UPZ BAZNAS dapat dibentuk oleh masyarakat dalam rangka menghimpun dana ZIS agar lebih tersistem dengan baik.

\section{Program-Program BAZNAS}

Dalam rangka mendistribusikan dan mendayagunakan dana zakat, infak, dan shadaqah (ZIS), BAZNAS menghadirkan program-program yang akan menunjang kehidupan para mustahik. Adapun program-program BAZNAS adalah:

\section{a. Zakat Community Development (ZCD)}

Zakat Community Development (ZCD) adalah program BAZNAS dalam rangka mengembangkan masyarakat dengan mengintegrasikan aspek sosial dan ekonomi secara komprehensif sehingga terwujud masyarakat sejahtera dan mandiri.

b. Rumah Sehat BAZNAS (RSB)

Rumah Sehat BAZNAS (RSB) merupakan program layanan kesehatan bersifat preventif, rehabilitatif, promotif, karitatif, yang ditujukan gratis untuk mustahik, khususnya fakir miskin dengan sistem membership.

c. Rumah Cerdas Anak Bangsa (RCAB)

Program BAZNAS ini ditujukan untuk memberikan bantuan berupa dana atau bimbingan bagi para siswa dan mahasiswa yang dikhususkan dalam bidang pendidikan dan pelatihan sehingga menjadi individu yang mandiri. d. Rumah Makmur BAZNAS/Baitul Qiradh BAZNAS (BQB)

Baitul Qiradh BAZNAS (BQB) adalah lembaga keuangan mikro syariah yang dibentuk oleh BAZNAS dengan berbadan hukum koperasi yang bertujuan untuk mendistribusikan dana ZIS secara produktif, baik melalui pinjaman kebajikan (Al Qardhul Hasan) maupun pembiayaan yang dikelola secara syariah.

e. Rumah Dakwah BAZNAS

Rumah Dakwah

BAZNAS

merupakan program pendistribusian zakat yang disalurkan kepada mualaf, kaderisasi seribu ulama dan berbagai aktivitas dakwah lainnya untuk masyarakat miskin di daerah terpencil dan terluar.

f. Kounter Layanan Mustahik

Kounter Layanan Mustahik (KLM) adalah tempat pelayanan mustahik yang dibentuk BAZNAS untuk memudahkan mustahik mendapatkan bantuan sesuai kebutuhannya.

g. Program Tanggap Bencana

Program Tanggap Bencana adalah program yang dilaksanakan khusus untuk memberikan bantuan kepada masyarakat yang tertimpa musibah.

\section{Sejarah Perolehan Sertifikasi ISO 9001:2008}

Sertifikasi ISO 9001:2008 dilakukan bertujuan untuk meningkatkan kepuasan para muzaki dan mustahik, meningkatkan mutu pelayanan, meningkatkan citra masyarakat terhadap BAZNAS, dan mendorong peningkatan kualitas para amil. Dengan tujuan tersebut, BAZNAS mulai melandasi kegiatan operasionalnya sesuai standar operasional yang ditetapkan. Sejak saat itu, kesadaran untuk menyusun prosedur yang jelas terdokumentasi dan 
sesuai standar internasional semakin besar. Pada tahun 2007, BAZNAS berusaha membangun kesadaran setiap divisi akan pentingnya standardisasi kebijakan lembaga secara internasional. Maka mulailah disusun rancangan kebijakan mutu, prosedur-prosedur ISO yang didampingi oleh konsultan ISO.

Setelah segala persiapan, dari mulai perancangan, pengenalan, pendidikan dan pelatihan, dan sebagainya sejak Juli 2008 BAZNAS mulai menerapkan ISO 9001:2000. Pada bulan Desember 2008, dilakukan audit eksternal oleh World Quality Assurance (WQA). Akhirnya, WQA merekomendasikan BAZNAS memperoleh sertifikasi ISO 9001:2000. Kemudian, pada tahun 2009 BAZNAS diaudit eksternal kembali oleh WQA dan memperoleh sertifikasi ISO untuk seri terbarunya yaitu ISO 9001:2008. Dengan perolehan ISO tersebut, BAZNAS menjadi lembaga pertama yang memperoleh sertifikasi ISO 9001:2008 untuk kategori seluruh unit kerja pada tahun 2009. Pelaksanaan audit eksternal oleh WQA ini dilakukan setiap satu tahun sekali dan sampai saat ini BAZNAS masih konsisten menerapkan ISO 9001:2008. Selanjutnya, pada tanggal 20 April 2016 BAZNAS akan diaudit eksternal kembali oleh WQA dengan seri ISO terbarunya yaitu ISO 9001:2015.

\section{Sistem Manajemen Mutu ISO 9001:2008 Di BAZNAS}

Sistem manajemen mutu yang diimplementasikan BAZNAS telah menjadi dasar dan pondasi dalam melaksanakan fungsi perencanaan, pelaksanaan, pengendalian, pelaporan, dan pertanggung jawaban atas penghimpunan, pendistribusian, dan pendayagunaan zakat yang diharapkan dapat meningkatkan pelayanan kepada pelanggannya. Sistem manajemen mutu ISO 9001:2008 yang diimplementasikan BAZNAS tertera dalam deskripsi berikut ini.

\section{Kebijakan dan Tujuan Mutu}

Kebijakan dan tujuan mutu BAZNAS ditetapkan oleh direktur pelaksana, kemudian disosialisasikan, dikomunikasikan, dan dipahami oleh seluruh amil BAZNAS. Kebijakan mutu BAZNAS adalah:

1. Pembinaan, pengembangan dan penyadaran kewajiban berzakat demi meningkatkan kesejahteraan serta kualitas kehidupan masyarakat.

2. Memberikan pelayanan yang terbaik bagi muzaki dan mustahik.

3. Membuat program pemberdayaan yang terencana dan berkesinambungan dalam meningkatkan taraf hidup mustahik menjadi muzaki.

4. Menyajikan data penerimaan dan pendayagunaan zakat yang akurat didukung oleh amil yang bekerja secara profesional.

5. Manajemen yang fokus terhadap pembinaan dan pengembangan sumber daya manusia sebagai amil yang amanah.

6. Selalu mengedepankan keselamatan dan kesehatan kerja bagi seluruh amil.

Adapun tujuan mutu BAZNAS adalah:

1. Menjadikan program unggulan BAZNAS sebagai mainstream (arus utama) program pendayagunaan Organisasi Pengelola Zakat (OPZ) seluruh Indonesia.

2. Memaksimalkan partisipasi organisasi pengelola zakat dalam mendukung program bersama pendayagunaan zakat nasional. 
3. Fokus kepada instansi pemerintah, BUMN dan Luar Negeri melalui penguatan regulasi.

4. Penguatan sentralisasi data nasional baik muzaki maupun jumlah penghimpunan.

5. Melakukan sosialisasi dan edukasi bersama.

6. Optimalisasi KKI (Koordinasi, Konsultasi, Informasi) melalui penyusunan mekanisme dan sistem koordinasi, penguatan lembaga serta SDM OPZ.

7. Meningkatkan kerjasama antar lembaga nasional dan internasional.

8. Intensifikasi dan ekstensifikasi hubungan kemitraan dan koordinasi dengan instansi pemerintah, BUMN, perbankan syariah, dan organisasi sosial/ keagamaan di dalam dan luar negeri.

9. Penyempurnaan Regulasi dan SOP.

10. Peningkatan sumber dana dan sumber daya.

11. Reorganisasi dan konsolidasi organisasi.

\section{Pedoman Mutu (Quality Manual)}

Pedoman mutu merupakan dokumen induk yang berisi tentang lingkup penerapan semua persyaratan standar ISO 9001:2008 termasuk kebijakan dan tujuan mutu. Persyaratan standar ISO 9001:2008 yang tercantum dalam pedoman mutu BAZNAS adalah:

\section{Bentuk dokumentasi sistem manajemen mutu BAZNAS.}

Bentuk dokumentasi sistem manajemen mutu ISO 9001:2008 BAZNAS meliputi kebijakan, tujuan, dan sasaran mutu; pedoman mutu, standar operasional prosedur (SOP), instruksi kerja; prosedur pengendalian dokumen, prosedur pengendalian catatan, prosedur audit internal, prosedur pengendalian produk tidak sesuai, prosedur tindakan dan pencegahan; dokumen yang diperlukan lembaga, catatan yang disyaratkan ISO 9001:2008, dan hirarki dokumentasi.

\section{Tanggung jawab manajemen BAZNAS}

Tanggung jawab manajemen BAZNAS terdiri dari komitmen ketua umum dan direktur pelaksana terhadap penerapan sistem manajemen mutu, memperhatikan muzaki, mustahik, dan BAZNAS daerah, menyusun perencanaan kerja yang terdiri dari sasaran mutu dan perencanaan sistem manajemen mutu. Selain itu, direktur pelaksana memastikan tanggung jawab dan wewenang seluruh amil sesuai job descriptionnya masing-masing, termasuk Wakil Manajemen Mutu yang bertanggung jawab menerapkan sistem manajemen mutu ISO 9001:2008. Dalam tanggung jawab manajemen BAZNAS perlu memastikan komunikasi di internal BAZNAS melalui rapat atau pengumuman lainnya dan tinjauan manajemen dalam rangka melakukan perbaikan dan perubahan sistem manajemen mutu apabila diperlukan.

\section{Pengelolaan sumber daya}

Dalam melakukan pengelolaan sumber daya, manajemen BAZNAS perlu menyediakan sumber daya untuk memenuhi ketentuan dalam standar ISO 9001:2008, menetapkan sumber daya manusia yang kompeten dan mampu menunaikan pekerjaannya, menyediakan sarana dan prasarana kerja yang sesuai dengan kebutuhan, dan menciptakan lingkungan kerja yang aman, nyaman dan sehat. 


\section{Realisasi produk}

Realisasi produk BAZNAS mencakup pelayanan sebagai koordinator zakat nasional dan operator. BAZNAS sebagai koordinator zakat nasional, melakukan koordinasi dan sosialisasi ZIS kepada BAZNAS daerah provinsi, kabupaten/kota dalam rangka menerima laporan penghimpunan dan menampung segala keluhan atau saran dari BAZNAS daerah, serta melakukan monitoring melalui prosedur pengukuran tingkat kepuasan BAZNAS daerah. Sedangkan BAZNAS sebagai operator bertujuan untuk mencari kepuasan muzaki dan mustahik dengan cara memberikan program penghimpunan dan penyaluran yang dibutuhkan, melakukan komunikasi yang baik dengan muzaki dan mustahik, dan menyiapkan segala yang dibutuhkan oleh muzaki dan mustahik.

Dalam realisasi produk ini terdapat klausul yang dikecualikan, yaitu klausul barang milik pelanggan dan peralatan pemantauan dan pengukuran. Klausulklausul ini tidak diimplementasikan BAZNAS karena tidak ada dalam operasional BAZNAS.

\section{Pengukuran, analisis dan peningkatan}

Pemantauan dan pengukuran dalam mencapai kepuasan muzaki dan mustahik termasuk BAZNAS daerah dilakukan oleh seluruh amil BAZNAS, sehingga seluruh amil dilatih untuk melakukan identifikasi dan mencatat setiap kejadian mengenai kepuasan atau ketidakpuasan muzaki, mustahik, dan BAZNAS daerah. Selain itu, untuk memastikan sistem manajemen mutu diimplementasikan dengan benar, maka dilakukan audit internal oleh auditor sistem manajemen yang terlatih dan berpengalaman setiap satu tahun sekali. Hasil dari audit internal tersebut, akan dievaluasi dalam rapat tinjauan manajemen untuk dilakukan perbaikan. Namun demikian, setiap permasalahan yang ditemukan dapat langsung dibicarakan dengan atasannya untuk diperbaiki sebelum atau sesudah terjadi.

\section{Prosedur Mutu (Standar Operasional Prosedur)}

Prosedur mutu BAZNAS menjelaskan proses pelayanan dan pengendalian proses-proses kunci yang ada pada setiap divisi. Prosedur mutu BAZNAS saat ini berjumlah 47 prosedur dengan rincian dapat dilihat pada Tabel 1 .

Tabel 1.Dokumen Prosedur Mutu (SOP)

\begin{tabular}{|c|c|c|}
\hline No. & Unit Kerja/Divisi/Bagian & $\begin{array}{l}\text { Jumlah } \\
\text { SOP }\end{array}$ \\
\hline 1. & $\begin{array}{lll}\text { Wakil } & \text { Manajemen } & \text { Mutu } \\
\text { (QMR) } & & \end{array}$ & 9 \\
\hline 2. & Penghimpunan & 4 \\
\hline 3. & $\begin{array}{ll}\text { Pendistribusian } & \text { dan } \\
\text { Pendayagunaan } & \end{array}$ & 3 \\
\hline 4. & Keuangan & 3 \\
\hline 5. & SDM & 6 \\
\hline 6. & Umum dan TI & 11 \\
\hline 7. & $\begin{array}{ll}\text { Perencanaan } & \text { dan } \\
\text { Pengembangan } & \end{array}$ & 2 \\
\hline 8. & Corsec dan Legal & 3 \\
\hline 9. & Satuan Audit Internal (SAI) & 6 \\
\hline & Jumlah & 47 \\
\hline
\end{tabular}

Dari keseluruhan prosedur mutu tersebut, terdapat prosedur mutu yang tidak diimplementasikan oleh BAZNAS, yaitu prosedur mutu terkait pengendalian barang milik pelanggan. Hal ini dikarenakan dalam operasional BAZNAS tidak ada pengendalian barang milik pelanggan, baik dari muzaki maupun mustahik. Prosedur mutu yang telah ditetapkan dapat dijadikan acuan untuk menyusun instruksi kerja yang menjelaskan bagaimana suatu pekerjaan dilaksanakan. 


\section{Instruksi Kerja (Work Instruction)}

Instruksi kerja ditetapkan bertujuan untuk mengendalikan aktivitas pekerjaan kunci dan tugas-tugas spesifik lain yang harus dikerjakan dengan cara-cara tertentu. Instruksi kerja BAZNAS saat ini berjumlah 38 instruksi dengan rincian pada Tabel 2 .

Tabel 2. Dokumen Instruksi Kerja

\begin{tabular}{|l|lc|c|}
\hline No. & \multicolumn{2}{|l|}{ Unit Kerja/Divisi/Bagian } & $\begin{array}{c}\text { Jumlah } \\
\text { IK }\end{array}$ \\
\hline 1. & $\begin{array}{l}\text { Wakil Manajemen Mutu } \\
\text { QMR) }\end{array}$ & 2 \\
\hline 2. & Penghimpunan dan & 7 \\
\hline 3. & $\begin{array}{l}\text { Pendistribusian } \\
\text { Pendayagunaan }\end{array}$ & 6 \\
\hline 4. & Keuangan & 7 \\
\hline 5. & SDM & 12 \\
\hline 6. & Umum dan TI & - \\
\hline 7. & $\begin{array}{l}\text { Perencanaan } \\
\text { Pengembangan }\end{array}$ & - \\
\hline 8. & Corsec dan Legal & - \\
\hline 9. & Satuan Audit Internal (SAI) & 38 \\
\hline & Jumlah & \\
\hline
\end{tabular}

Sumber: BAZNAS, 2016

\section{Dokumen dan Rekaman}

Dokumen dan rekaman BAZNAS berupa dokumen-dokumen pendukung dan formulir-formulir yang digunakan oleh masing-masing divisi. Dokumen pendukung saat ini berjumlah 100 dokumen dengan rincian diuraikan pada tabel 3.
Tabel 3. Dokumen Pendukung

\begin{tabular}{|l|l|c|}
\hline No. & \multicolumn{1}{|c|}{$\begin{array}{c}\text { Unit } \\
\text { Kerja/Divisi/Bagian }\end{array}$} & $\begin{array}{c}\text { Jumlah } \\
\text { Dokumen }\end{array}$ \\
\hline 1. & $\begin{array}{l}\text { Wakil Manajemen Mutu } \\
\text { QMR) }\end{array}$ & 12 \\
\hline 2. & Penghimpunan & 9 \\
\hline 3. & $\begin{array}{l}\text { Pendistribusian dan } \\
\text { Pendayagunaan }\end{array}$ & 10 \\
\hline 4. & Keuangan & 10 \\
\hline 5. & SDM & 14 \\
\hline 6. & Umum dan TI & 9 \\
\hline 7. & $\begin{array}{l}\text { Perencanaan } \\
\text { Pengembangan }\end{array}$ & 9 \\
\hline 8. & Corsec dan Legal & - \\
\hline 9. & $\begin{array}{l}\text { Satuan Audit Internal } \\
\text { (SAI) }\end{array}$ & 100 \\
\hline & Jumlah \\
\hline
\end{tabular}

Sumber: BAZNAS, 2016

Sedangkan formulir yang ada saat ini berjumlah 139 formulir, yang dapat dilihat pada tabel 4 .

Tabel 4. Formulir

\begin{tabular}{|c|c|c|}
\hline No. & Unit Kerja/Divisi/Bagian & $\begin{array}{l}\text { Jumlah } \\
\text { Formulir }\end{array}$ \\
\hline 1. & $\begin{array}{lll}\text { Wakil Manajemen } & \text { Mutu } \\
\text { (QMR) } & & \end{array}$ & 19 \\
\hline 2. & Penghimpunan & 12 \\
\hline 3. & $\begin{array}{ll}\text { Pendistribusian } & \text { dan } \\
\text { Pendayagunaan } & \end{array}$ & 19 \\
\hline 4. & Keuangan & 13 \\
\hline 5. & SDM & 27 \\
\hline 6. & Umum dan TI & 38 \\
\hline 7. & $\begin{array}{l}\text { Perencanaan } \\
\text { Pengembangan }\end{array}$ & 0 \\
\hline 8. & Corsec dan Legal & 0 \\
\hline 9. & Satuan Audit Internal (SAI) & 11 \\
\hline & Jumlah & 139 \\
\hline
\end{tabular}

Sumber: BAZNAS, 2016

Implementasi Sistem Manajemen Mutu ISO 9001:2008 Di Badan Amil Zakat Nasional

Uji Reliabilitas dan Validitas

Uji reliabilitas digunakan untuk mengetahui sejauh mana instrumen pengukuran dapat dipercaya dan 
memberikan hasil yang konsisten. Hasil pengujian reliabilitas yang diuji dari semua pernyataan dinyatakan reliabel, karena nilai koefisien cronbach's alpha diperoleh lebih besar dari 0,06 $(\alpha>0,6)$ yaitu sebesar 0,981 . Dengan demikian, maka instrumen yang digunakan dalam penelitian ini cukup handal dalam mengukur responden terhadap variabel yang diteliti dan dapat dilanjutkan ke tahap selanjutnya.

Sedangkan uji validitas dari semua item pertanyaan ini yang berjumlah 47 pertanyaan menunjukkan nilai corrected item total correlation sebesar $>0,361$. Ini artinya bahwa semua item pertanyaan dinyatakan valid dan dapat diolah lebih lanjut.

\section{Analisis Faktor}

Penelitian ini dilakukan menggunakan 18 variabel yang disebar melalui 47 pertanyaan kuesioner yang mengarahkan responden pada variabel mana yang menjadi faktor utama dan faktor pendukung dalam implementasi sistem manajemen mutu ISO 9001:2008. Proses analisis faktor ini dapat dilihat pada tahapan berikut ini.

\section{Uji Kaiser Mayer Olkin (KMO)}

Dari hasil pengolahan data dengan program SPSS 22 diperoleh output hasil pengolahan data Kaiser Mayer Olkin Measure Of Sampling Adequecy (KMO-MSA) sebesar 0,814. Hasil ini termasuk pada hasil kategori baik mengingat angka ini sudah di atas 0,5. Adapun nilai bartlett's of sphericity mempunyai nilai 608,662 dengan nilai signifikansi 0,000 . Nilai ini berarti bahwa faktor pembentuk variabel sudah baik dan bisa dianalisis lebih lanjut.

Proses Ekstraksi

Hasil penelitian menunjukkan bahwasanya variabel yang memiliki nilai extraction tertinggi adalah proses yang berkaitan dengan pelanggan dengan nilai sebesar 0,872. Hal ini berarti 87,2\% varian variabel proses pelanggan akan terbentuk. Kemudian untuk variabel kebijakan mutu $78,4 \%$, manual mutu 58,2\%, pengendalian rekaman $74,1 \%$, pengendalian dokumen $81 \%$, analisa data $81,9 \%$, sumber daya manusia $76,9 \%$, sarana prasarana $77,2 \%$, lingkungan kerja 72,6\%, komunikasi $86,9 \%$, desain pengembangan $64,8 \%$, penyediaan barang $73,8 \%$, produksi dan penyediaan jasa $79,4 \%$, pengukuran $78,3 \%$, pengendalian produk yang tidak sesuai $83,4 \%$, tinjauan manajemen $70,5 \%$, perbaikan $80,7 \%$, dan variabel perencanaan mempunyai nilai extraction terendah 0,53. Hal ini berarti 53\% varian dari variabel perencanaan dapat dijelaskan oleh faktor yang akan terbentuk. Variabel yang semakin besar nilai communalitiesnya menunjukkan semakin kuat hubungan dengan faktor yang nantinya akan terbentuk.

Selanjutnya, berdasarkan pengolahan data dengan SPSS 22 didapatkan hasil bahwa 18 variabel yang digunakan dalam penelitian ini akan dikelompokkan ke dalam 2 faktor, yaitu:

Faktor pertama yang memiliki nilai eigenvalue sebesar 12,236 dengan varian $67,979 \%$. Faktor kedua yang memiliki nilai eigenvalue sebesar 1,346 dengan varians 7,475\%.

Hasil tersebut menunjukkan bahwa faktor 1 mampu menjelaskan seluruh varians sebesar $67,979 \%$ dan faktor 2 menjelaskan seluruh varians sebesar 7,475\%. Sedangkan berdasarkan kumulatif seluruh faktor dapat menjelaskan varians sebesar 75,454 \%. Hal ini berarti bahwa masih terdapat variabel-variabel lain yang 
menjadi indikator dalam implementasi sistem manajemen mutu ISO 9001:2008.

Setelah mendapat 2 faktor adalah jumlah yang paling optimal, maka analisis selanjutnya dilakukan pada component matrix yang menunjukkan distribusi 18 variabel pada 2 faktor yang terbentuk. Angka-angka yang terdapat pada tabel component matrix merupakan factor of loading yang menunjukkan besar korelasi antara suatu variabel dengan faktor pertama dan kedua. Proses penentuan variabel asal kedalam faktor dilakukan dengan membandingkan besar korelasi tiap baris yang didasarkan pada angka mutlak factor of loading yang diberikan setiap variabel terhadap masing-masing faktor.

Berdasarkan nilai component matrix terlihat bahwasannya keseluruhan variabel berada pada faktor 1 dengan nilai factor of loading lebih dari 0,5 dan tidak ada variabel yang masuk kepada faktor 2 karena keseluruhan nilai factor of loading kurang dari 0,5. Padahal syarat suatu variabel masuk ke dalam suatu faktor nilai loading of factor harus di atas 0,5. Maka dari itu, perlu adanya proses rotasi agar component 2 memiliki nilai factor of loading yang besar, sehingga dapat terlihat variabel mana yang masuk pada component 2 . Proses rotasi dalam penelitian ini menggunakan metode varimax yang bertujuan untuk memperbesar nilai loading of factor yang dulunya memang sudah besar dan memperkecil nilai loading of factor yang dulunya memang sudah kecil.

Setelah dilakukan rotasi, maka dapat dengan mudah menentukan variabelvariabel mana yang akan masuk kedua faktor tersebut. Dari hasil rotated component matrix dapat dilihat bahwa variabel yang termasuk dalam component 1 yaitu variabel analisa data $(0,761)$, sarana dan prasarana $(0,714)$, lingkungan kerja $(0,792)$, komunikasi $(0,705)$, penyediaan barang $(0,681)$, produksi dan penyediaan jasa $(0,854)$, pengukuran $(0,834)$, pengendalian produk yang tidak sesuai $(0,854)$, tinjauan manajemen $(0,795)$, dan perbaikan $(0,823)$. Hal ini berarti bahwa variabel tersebut mempunyai korelasi yang tinggi terhadap faktor 1 . Kemudian untuk component 2 yaitu variabel kebijakan mutu $(0,787)$, perencanaan $(0,705)$, manual mutu $(0,746)$, pengendalian rekaman $(0,770)$, pengendalian dokumen $(0,770)$, proses dengan pelanggan $(0,679)$, sumber daya manusia $(0,715)$, dan desain pengembangan $(0,577)$.

Hasil analisis faktor dengan 18 variabel yang diteliti menggunakan metode ekstraksi principle component analysis yang direduksi menjadi 2 faktor dimana variabel analisa data, sarana prasarana, lingkungan kerja, komunikasi, penyediaan barang, produksi dan penyediaan jasa, pengukuran, pengendalian produk yang tidak sesuai, tinjauan manajemen dan perbaikan masuk kepada faktor 1. Sedangkan variabel kebijakan mutu, perencanaan, manual mutu, pengendalian rekaman, pengendalian dokumen, proses dengan pelanggan, sumber daya manusia, dan desain pengembangan masuk kepada faktor 2 .

\section{Penamaan faktor}

Berdasarkan hasil penelitian dari analisis faktor yang telah dijelaskan di atas, maka dapat ditemukan persamaan matemastis dari kedua faktor yaitu sebagai berikut:

$$
\begin{aligned}
F_{1}= & 0,761 X_{7}+0,714 X_{9}+0,792 X_{10}+0,705 \\
& X_{11}+0,681 X_{13}+0,854 X_{14}+0,834 X_{15}+ \\
& 0,854 X_{16}+0,795 X_{17}+0,823 X_{18}
\end{aligned}
$$


Dimana: $\mathrm{X}_{7}=$ Analisa data, $\mathrm{X}_{9}=$ Sarana prasarana, $\mathrm{X}_{10}=$ Lingkungan kerja, $\mathrm{X}_{11}=$ Komunikasi, $\mathrm{X}_{13}=$ Penyediaan barang, $\mathrm{X}_{14}=$ Produksi dan penyediaan jasa, $\mathrm{X}_{15}=$ Pengukuran, $\mathrm{X}_{16}=$ Pengendalian produk tidak sesuai, $\mathrm{X}_{17}=$ Tinjauan manajemen, $\mathrm{X}_{18}$ $=$ Perbaikan

Faktor pertama ini memiliki nilai eigenvalue sebesar 12,236, sehingga dapat disimpulkan bahwa faktor ini merupakan faktor paling dominan dalam implementasi sistem manajemen mutu ISO 9001:2008 di BAZNAS. Faktor 1 ini dapat menerangkan keragaman data sebesar 67,979\%.

$F_{2}=0,787 X_{1}+0,705 X_{2}+0,746 X_{3}+0,770$

$\mathrm{X}_{4}+0,770 \mathrm{X}_{5}+0,679 \mathrm{X}_{6}+0,715 \mathrm{X}_{8}+$ $0,577 X_{12}$

Dimana: $\mathrm{X}_{1}=$ kebijakan mutu, $\mathrm{X}_{2}=$ perencanaan, $X_{3}=$ manual mutu, $X_{4}=$ pengendalian rekaman, $\mathrm{X}_{5}=$ pengendalian dokumen, $\mathrm{X}_{6}=$ proses dengan pelanggan, $\mathrm{X}_{8}$ $=$ sumber daya manusia, $\mathrm{X}_{12}=$ dan desain pengembangan.

Berdasarkan hasil penelitian dari analisis faktor, diperoleh dua faktor yang menjadi acuan dalam implementasi sistem manajemen mutu ISO 9001:2008 di BAZNAS. Dua faktor tersebut dibagi menjadi faktor utama dan faktor pendukung. Faktor utama terdiri dari analisa data $(0,761)$, sarana dan prasarana $(0,714)$, lingkungan kerja $(0,792)$, komunikasi $(0,705)$, penyediaan barang $(0,681)$, produksi dan penyediaan jasa $(0,854)$, pengukuran $(0,834)$, pengendalian produk yang tidak sesuai $(0,854)$, tinjauan manajemen $(0,795)$, dan perbaikan $(0,823)$. Sedangkan faktor pendukung terdiri dari kebijakan mutu $(0,787)$, perencanaan (0,705), manual mutu $(0,746)$, pengendalian rekaman $(0,770)$, pengendalian dokumen $(0,770)$, proses dengan pelanggan $(0,679)$, sumber daya manusia $(0,715), \quad$ dan desain pengembangan $(0,577)$.

1. Importance Performance Analysis (IPA)

Dalam analisis IPA ini sangat penting adanya suatu kesenjangan atribut (gap analisis). Kesenjangan atribut ini diperoleh dari skor kenyataan (ei) yang dilakukan dan harapan (bi) yang didapatkan. Rumus yang digunakan untuk memperoleh kesenjangan (gap) adalah: "Gap = Rata-rata kenyataan - Rata-rata harapan".

Dari hasil analisis gap, terlihat bahwasanya variabel-variabel yang ada saat ini belum sepenuhnya sesuai dengan harapan. Dengan demikian, maka pihak manajemen dapat lebih memahami bahwa nilai kenyataan dari harapan masih memiliki beberapa kekurangan yang bisa menjadi masukan untuk perbaikan kedepannya.

Setelah memahami tingkat analisis gap dari variabel di atas, maka selanjutnya adalah melakukan analisis Importance Performance Analysis (IPA). Analisis IPA dimulai dengan menghitung rata-rata tingkat realitas atau kenyataan (X) dan tingkat harapan atau kepentingan (Y). Setelah menghitung tingkat rata-rata $\mathrm{X}$ dan $\mathrm{Y}$, selanjutnya ratakan kembali nilai $\mathrm{X}$ dan $\mathrm{Y}$, dimana nilai rata-rata tersebut akan menjadi pembatas dalam diagram IPA. Adapun hasil rata-rata tingkat performance (X) adalah 3,93. Nilai tersebut akan digunakan sebagai batas kuadran dalam analisis IPA. Untuk itu, setelah mengetahui hasil perhitungan perhitungan rata-rata performance, maka selanjutnya akan mencari rata-rata tingkat kepentingan (importance), maka perhitungan rata-rata tingkat kepentingan adalah 4,10. Nilai tersebut akan digunakan sebagai batas kuadran IPA pada sumbu Y. Nilai-nilai tersebut akan dimasukkan kedalam 
diagram Importance Performance Analysis (IPA) yang dibagi menjadi 4 kuadran, diantaranya adalah:

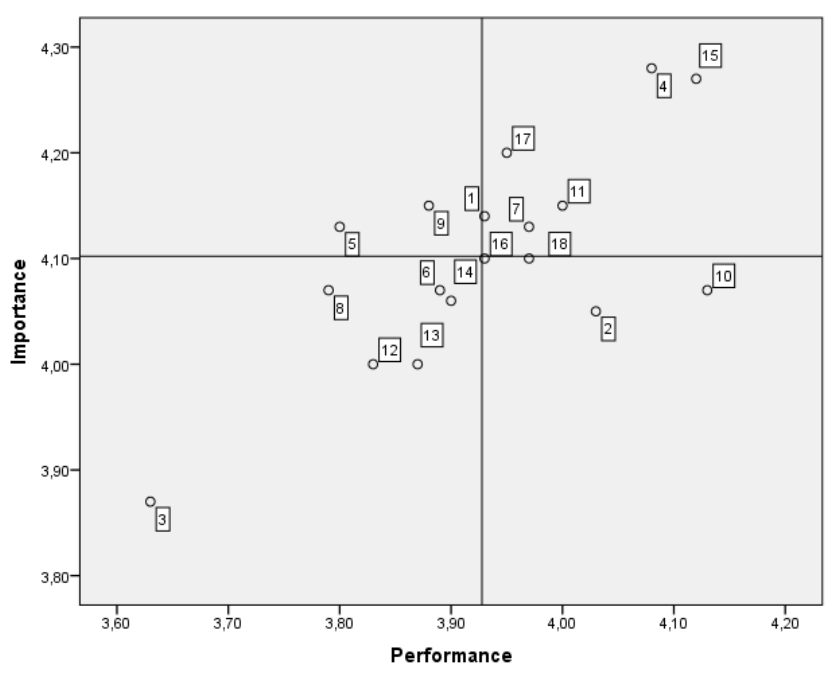

Gambar 2.

Importance Performance Analysis BAZNAS

Diagram 2. menunjukkan bahwa variabel-variabel tingkat implementasi sistem manajemen mutu ISO 9001:2008 di BAZNAS dibagi menjadi 4 kuadran, diantaranya adalah:

a. Kuadran A

Pada kuadran ini (A) dianggap sebagai faktor yang sangat penting oleh amilin, namun pada kenyataannya faktor-faktor ini belum diimplementasikan dengan baik, sehingga faktor-faktor dalam kuadran ini perlu ditingkatkan kembali, yang termasuk dalam kuadran ini adalah perencanaan (5) dan sarana prasarana (9).

b. Kuadran B

Pada kuadran ini (B) dianggap sebagai faktor yang penting atau diharapkan oleh amilin dan pada kenyataannya faktorfaktor ini telah diimplementasikan pada unit kerja, maka dari itu wajib dipertahankan. Adapun yang termasuk dalam kuadran ini adalah pengendalian dokumen (1), kebijakan mutu (4), tinjauan manajemen (7), proses dengan pelanggan (11), pengukuran (15), pengendalian produk tidak sesuai (16), analisa data (17), dan perbaikan (18).

c. Kuadran C

Pada kuadran ini (C) dianggap sebagai faktor-faktor yang kurang penting atau kurang diharapkan oleh amilin, sehingga tingkat implementasi pada level unit kerjanya biasa-biasa saja, yang termasuk dalam kuadran ini adalah manual mutu (3), komunikasi (6), sumber daya manusia (8), desain pengembangan (12), penyediaan barang (13), dan produksi dan penyediaan jasa (14) .

d. Kuadran D

Pada kuadran ini (D) dianggap sebagai faktor-faktor yang kurang penting atau kurang diharapkan oleh amilin, akan tetapi implementasinya dirasakan oleh amilin bahkan berlebihan, yang termasuk dalam kuadran ini adalah pengendalian rekaman (2) dan lingkungan kerja (10).

Dalam penelitian ini, terdapat dua pertanyaan yang menjadi fokus penelitian yaitu pertama, bagaimana sistem manajemen mutu ISO 9001:2008 di Badan Amil Zakat Nasional. Untuk menjawab pertanyaan penelitian ini, peneliti menggunakan analisis deskriptif berdasarkan pedoman mutu, BAZNAS matrix system documentation, format standar operasional prosedur, format instruksi kerja, serta format dokumen pendukung yang dimiliki dan diimplementasikan BAZNAS. Berdasarkan analisis deskriptif tersebut, maka disimpulkan bahwa sistem manajemen mutu ISO 9001:2008 di Badan Amil Zakat Nasional terdiri dari lima struktur dokumen, yaitu struktur dokumen 1 memuat kebijakan mutu, struktur dokumen 2 memuat pedoman mutu, struktur dokumen 3 memuat prosedur mutu, struktur dokumen 4 memuat instruksi 
kerja, dan struktur dokumen 5 memuat dokumen dan rekaman.

Pertanyaan kedua dari penelitian ini adalah bagaimana implementasi sistem manajemen mutu ISO 9001:2008 di Badan Amil Zakat Nasional. Dari pertanyaan kedua ini, terdapat hipotesis yang harus dibuktikan yaitu sebagai berikut:

H0 : Implementasi sistem manajemen mutu BAZNAS tidak sesuai dengan ISO 9001:2008.

H1 : Implementasi sistem manajemen mutu BAZNAS sesuai dengan ISO 9001:2008. Setelah melakukan penelitian mengenai implementasi sistem manajemen mutu ISO 9001:2008 di Badan Amil Zakat Nasional dengan menggunakan analisis faktor dan Importance Performance Analysis (IPA) menyatakan bahwasanya implementasi sistem manajemen mutu di BAZNAS pada level unit kerja sesuai dengan ISO 9001:2008. Hal ini berarti bahwa $\mathrm{H} 1$ diterima dan $\mathrm{H0}$ ditolak, artinya bahwa implementasi sistem manajemen mutu pada level unit kerja di BAZNAS sesuai dengan ISO 9001:2008. Akan tetapi, dalam implementasi sistem manajemen mutu tersebut masih terdapat persyaratanpersyaratan setiap klausul ISO 9001:2008 yang tingkat implementasinya masih rendah, yaitu perencanaan (5) dan sarana dan prasarana (9). Namun demikian, sistem pendokumentasian di BAZNAS sudah sesuai dengan persyaratan setiap klausul ISO 9001:2008.

\section{KESIMPULAN DAN IMPLIKASI}

Berdasarkan hasil penelitian yang dilakukan di Badan Amil Zakat Nasional (BAZNAS) mengenai implementasi sistem manajemen mutu ISO 9001:2008 dapat ditarik kesimpulan, sebagai berikut:
Sistem manajemen mutu di Badan Amil Zakat Nasional terdiri dari 5 struktur dokumen ISO 9001:2008, yaitu struktur 1 memuat kebijakan mutu, struktur 2 memuat pedoman mutu, struktur 3 memuat prosedur mutu, struktur 4 memuat intruksi kerja, dan struktur 5 memuat dokumen dan rekaman.

Berdasarkan hasil analisis faktor terdapat faktor-faktor yang menjadi faktor utama dan faktor pendukung dalam implementasi sistem manajemen mutu ISO 9001:2008 di BAZNAS. Faktor utama tersebut adalah analisa data, sarana dan prasarana, lingkungan kerja, komunikasi, penyediaan barang, produksi dan penyediaan jasa, pengukuran, pengendalian produk yang tidak sesuai, tinjauan manajemen, dan perbaikan. Sedangkan faktor pendukung terdiri dari kebijakan mutu, perencanaan, manual mutu, pengendalian rekaman, pengendalian dokumen, proses dengan pelanggan, sumber daya manusia, dan desain pengembangan. Adapun berdasarkan hasil Importance Performance Analysis (IPA) menyimpulkan bahwa implementasi sistem manajemen mutu ISO 9001:2008 di BAZNAS, telah sesuai dengan ISO 9001:2008. Akan tetapi, masih terdapat variabel-variabel yang tingkat implementasinya masih rendah yaitu variabel perencanaan (5) serta sarana dan prasarana (9)

\section{DAFTAR PUSTAKA}

Hafidhuddin, Didin dan Hendri Tanjung. 2003. Manajemen Syariah Dalam Praktik. Jakarta: Gema Insani Press.

Huda, Nurul dan Mohamad Heykal. 2010. Lembaga Keuangan Islam: Tinjauan Teoritis dalam Praktis. Jakarta: Kencana Prenada Media Group. 
Nasution, M. N. 2001. Manajemen Mutu Terpadu (Total Quality Management). Jakarta: Ghalia Indonesia.

Siswanto, B. 2005. Pengantar Manajemen. Jakarta: Bumi Aksara.

Sugiyono. 2014. Metode Penelitian Kuantitatif, Kualitatif, dan $R \& D$. Bandung: Alfabeta.

Rusdiana, Febriyan. 2010. Analisis Penerapan ISO 9001:2000 Pada Badan Amil Zakat Nasional, Jakarta. Skripsi. Fakultas Ekonomi dan Manajemen Institut Pertanian Bogor.

SNI ISO 9001:2008. 2016. Sistem Manajemen Mutu - Persyaratan. Diunduh tanggal 4 Februari 2016 dari https://if08030.files.wordpress.com/20 11/06/sni_iso9001_2008.pdf

SNI ISO 9000:2005. 2016. Sistem Manajemen Mutu - Dasar-dasar dan Kosakata.Diunduh tanggal 4 Februari 2016 dari https://if08030.files.wordpress.com/20 11/06/sni_iso9001_2008.pdf 